\title{
The Investigation of Pre Service Science Teachers' Epistemological Beliefs According to Some Variables
}

\author{
Mehmet Yalcin ${ }^{1}$, Fatma Aggul Yalcin ${ }^{1}$ \\ ${ }^{1}$ Agri Ibrahim Cecen University Education Faculty, Agri, Turkey \\ Correspondence: Mehmet Yalcin, Agri Ibrahim Cecen University Education Faculty, 04000, Agri, Turkey.
}

Received: February15, 2017

Accepted: March 15, 2017

Online Published: September 25, 2017

doi:10.11114/jets.v5i10.2224

URL: https://doi.org/10.11114/jets.v5i10.2224

\begin{abstract}
The present study aimed to investigate the relationship between pre service science teachers' scientific epistemological beliefs and academic achievements and change of the beliefs with regard to the variables such as, grade level and gender. In the research in which survey method as research approach, the sample consisted of total 258 pre service teachers. Data was collected by "Epistemological beliefs scale" with 26 items developed by Conley et al. (2004). The data collected were analyzed using two way variance analysis. The statistical analysis showed that there is no a statistically significant difference in pre-service science teachers' epistemological beliefs with regard to grade level and gender in the pooled data without considering sub dimensions of scale. But, in certainty of scientific knowledge sub dimension, no statistically significant difference was found according to gender, but a significant difference for grade level. Moreover, for justification of scientific knowledge sub dimension, the results showed that no pre service teachers' epistemological beliefs differ with respect to gender, while there was statistically significant difference according to grade level. Again, it was found that the there is no statistically significant correlation between pre-service science teachers' scientific epistemological beliefs and academic
\end{abstract}

Keywords: epistemological beliefs, teacher education, pre service science teaching

\section{Introduction}

In recent years teaching programs are designed with respect to Constructivist approach, a constructivist approach is student-centered active learning process. One of the most important factors for the application of Instructional programs in accordance with the curriculum philosophy is the epistemological beliefs of teachers. The epistemological beliefs of teachers have influence on their choice of teaching methods and techniques, classroom management, how to arrange education and training activities and the recommendation of what kind of learning environment to their students. Such beliefs play an important role on teachers' knowledge organization in the classroom (Chan and Eliot 2000).

Epistemological beliefs reflect properties of what is knowledge, how it is acquired, the limits and the degree of certainty of knowledge (Perry 1981; Schommer 1990; Hofer and Pintrich 1997). Individuals' Epistemological beliefs in general can be divided into two groups. According to those in the first group, knowledge is the absolute and has a structure consisting of unrelated individual pieces. It is constructed by a specialist and transferred to the students by him. Individuals have innate ability to learn a specific subject. These are individuals who have undeveloped epistemological beliefs. For the second group, who have developed epistemological beliefs, knowledge consists of a large number of interrelated parts that have a complex structure is not absolutely accurate. It is created by the individual through reason and empirical evidence. The ability to learn can be developed and learning is dependent of the individual efforts of individuals (Deryakulu, 2002).

\subsection{Review of Previous Research of Epistemological Beliefs}

There are so many studies conducted on the epistemological beliefs ( Buehl and Alexander 2001; Dahl et al. 2005; Enman and Lupart 2000; Hammer 1994; Havdala and Ashkenazi 2007; Hofer 2001; Hofer and Pintrich 1997; Jehng et al.1993; Kardash and Howell 2000; Lee and Tsai 2012; Mason et al. 2013; Ravindran et al. 2005; Rizk et al.2012; Schommer et al. 2012; Tolhurst 2007; Tsai 1999; Kittleson 2011; Zinn 2012). The previous research showed considerable evidences that throughout education epistemological beliefs undergo change and become more sophisticated/developed transiting from low grades to high grades (Schommer 1993; Ozdemir and Koksal 2014; Kurt 2009; Yılmaz Tuzun and Topcu 2013; Ogan Bekiroglu and Sengul Turgut 2011; Cano 2005; Tolhurst 2007; De-Juanas 
and Beltran 2012). It was shown that epistemological beliefs influenced also academic achievement, as well as a students' learning approaches (Mason et al. 2013; Cano 2005; De-Juanas and Beltran 2012; Chan 2011) and related closely with to students' metacognitive behaviors (Pulmones 2010; Belet and Guven 2011; Akar, Tekkaya and Cakıroglu 2011). It was explored that the individual with sophisticated epistemological beliefs have high academic achievement and more effective learning and study strategies. They are more successful in controlling to what extent they comprehend new knowledge (Schommer 1990; Schommer, Crouse and Rhodes 1992; Deryakulu 2002). Moreover, there are the findings emphasizing that many of the student's difficulties were epistemological in nature (Lising and Elby 2005).

Some studies were conducted on epistemological beliefs and these studies focus on teacher or pre-service teacher' epistemological beliefs of learning and teaching (Deryakulu 2002; Oksal, Sensekerci and Bilgin 2006; Topcu 2011; Saylan, Bektas and Oner Armagan 2015; Yenice and Ozden, 2013; Yildiran et al. 2011). In a study performed by Schommer (1993), it was investigated the development of secondary students' beliefs about the nature of knowledge and learning, or epistemological beliefs, and the influence that these beliefs have on academic performance. The findings revealed that belief in simple knowledge, certain knowledge, and quick learning decreased from freshman to senior year. Girls were less likely to believe in quick learning and fixed ability. The findings showed that the less students believed in quick learning, the higher the GPA they earned. The results of a study performed by Liang et al. (2010) on science-major undergraduates indicated some significant relations between scientific epistemological beliefs and approaches to learning science. According to this study, a surface strategy for learning science was found to be negatively predicted by the maturation of beliefs about the source and certainty of scientific knowledge. Beliefs about justification of scientific knowledge appear to positively contribute to deep strategies. In addition, the results reveal that a deep motive for learning science could be positively affected by beliefs about the development and justification of scientific knowledge. In particular, beliefs about justification of scientific knowledge appear to have positive effects on mixed motives for learning science (Liang et al. 2010). In a study administered to pre-service teacher education students to examine their epistemological beliefs and conceptions of learning. Results showed epistemological beliefs had significant relationship with conceptions of learning, implying epistemological beliefs play an important role in students' learning (Chan 2011).

Ogan Bekiroglu and Sengul Turgut (2011) aimed to determine if high school students' general epistemological beliefs were different from their epistemological beliefs in the domain of physics. They argued both students' general and physics epistemological beliefs can change and improve to higher levels. However, since beliefs are multidimensional, changes or improvements in one dimension of beliefs do not have to occur in other dimensions. In literature, the studies of whether epistemological beliefs of teachers, teacher candidates and other students vary with gender revealed contradictory results. Apart from the findings which suggest the belief differ by gender (Schommer 1993; Aytunga 2008; Ertekin, Dilmac, Delice and Aydın 2009; Aypaya 2010; Meral and Colak 2009; De-Juanas and Beltran 2012 ; Belet and Guven 2011; Terzi, Sahan and Celik 2015; Deniz 2014; Onen 2011; Topcu and Y1lmaz Tuzun 2009; Er 2013; Kurt 2009; Yılmaz Tuzun and Topcu 2013), other some studies report that there is no any difference with respect to gender (Yenice 2015; Tumkaya 2012; Eren 2007; Kaygin, Bas, Kanbolat and İnenc 2010). The further contradictory results were also found for the variables, such as grade level, enrolled program. In some research findings, it was explored some sub-dimensions of epistemological beliefs change with grade level (Kurt 2009; Onen 2011; Eren 2007; Akyuzluer 2014; Belet and Guven 2011: Tumkaya 2012; Aypaya 2010; Isıksal, Kurt, Dogan and Cakıroglu 2007). Some Findings indicated that no this belief Change with Grade Level (Meral and Colak 2009; Yenice 2015). while some research findings emphasized with respect to the enrolled university program epistemological beliefs change (Liu, And Tsai 2008; Kurt 2009; Er 2013; Ozdemir and Koksal 2014; Terzi, Sahan, and Celik 2015; Meral and Colak 2009; Ertekin et al. 2009; Aypaya 2010; Tumkaya 2012; Palmer and Marra 2004), some other research finding showed that epistemological beliefs are not related to enrolled program (Kaygin, Bas, Kanbolat and İnenc 2010; Schommer and Walker 1995). In addition, there is the findings that domain-general and domain-specific epistemological beliefs co-exist for different science programs (Lee and Tsai 2012). Some results pointed out differences of the belief according to type of school attained (Bayrak, Cinar, Coban and Coskuner 2013; Er 2013). Other one variable was education level of parents. Research results of change of epistemological beliefs regarding education level of parents were no conclusive (Deniz 2014; Topcu and Yilmaz Tuzun 2009; Er 2013).

In a study conducted by Liang and Tsai (2010) it was found that there is a significant relationship between students' epistemological beliefs and their attitudes toward science learning. Findings of Schreiber and Shinn (2003) indicated that students' epistemological beliefs had influence on their academic achievements, learning processes and performance. There are the findings from further researches which support these claims (Schommer 1993; Kaymak and Ogan Bekiroglu 2013; Onen 2011; Topcu and Y1lmaz Tuzun 2009; Y1lmaz Tuzun and Topcu 2013; Chan 2011; Lising and Elby 2005). But, there are the findings (Belet and Guven 2011) that there is no any relationship between academic 
achievement and epistemological belief, which are not compatible with those of mentioned above. Chan (2003) demonstrated that students believed that the view that no ability to learn is innate and no knowledge is absolute, contrary to this, their beliefs of an authority transferring knowledge from generation to generation are high.

Epistemological beliefs of teachers are an important factor affecting students' epistemological belief with whom they are interacting in constant in class. The studies of teachers' epistemological beliefs indicated that scientific epistemological beliefs are closely related to their teaching approach in class (Meral and Colak 2009). Therefore, it is crucial that gaining knowledge of teachers' epistemological beliefs provide valuable knowledge of their students. Epistemological beliefs reflect what the knowledge is and how it is acquired, the boundaries and certainty degree of knowledge. Pre service teachers' epistemological beliefs provide us with the knowledge about the beliefs that their students are to gain in future. Moreover, given that it is decisive in pre service teachers' instructional planning, implementation and their relationship with their students, it is thought that it is crucial that investigating and probing epistemological beliefs with respect to variety of variables, thus, the present study aimed to investigate the beliefs with regard to the variables such as, grade level and gender and to reveal the relationship between pre-service science teachers' scientific epistemological beliefs and academic achievements.

\section{Method}

In this study, the survey method was used, which is one method used to explore people's attitudes, beliefs, values, habits and thoughts about various topics (McMillian and Schumacher 2004, p. 304).

\subsection{Sample}

The sample consists of a total 258 Science Teacher candidates enrolled department of primary education in two state Universities, Turkey (144 first grades and 114 fourth grades). The sample included 141 female and 117 male students with ages varying from 18 to 24

\subsection{Instruments}

Data is collected using a epistemological beliefs scale with 26 items developed by Conley, Pintrich, Vekiri and Harrison (2004). The scale was translated into Turkish by the researchers and arranged according to language experts and the experts' opinions. Epistemological belief scale with 5 Likert-type includes the judgments such as, strongly disagree, disagree, undecided, agree and strongly agree, respectively. For the scale implemented to the similar group, the reliability coefficient alpha of the scale is determined to be 0.79 . The scale consists of four sub-parts, namely, a source of scientific knowledge, certainty of scientific knowledge, development of scientific knowledge and justification of scientific knowledge. The first sub-section contains the items about, the dependence of knowledge to some external authorities such as "scientists know just what knowledge is". In the other sub-section, certainty of knowledge, there is the statements about nature of knowledge such as, "of all questions in science, there is only one right answer". In the third subsection it is aimed to reveal students' perception of changeability of scientific knowledge using some items, for example, "Sometimes scientists change their ideas about what they think that it is right". The last sub-section measures, how people justify scientific knowledge and role of experiments in this context. For example, the statements "The best way to find out if something is true is to do experiment" serves for this purpose.

\subsection{Analysis of Data}

The data collected using epistemological beliefs scale was analyzed statistically. Two -way analysis of variance was performed to explore whether there is any statistically significant difference in teachers' epistemological beliefs with respect to gender and grade level (two main effects). To the analysis, it was added an interaction term to determine whether the effect of one variable on epistemological belief differs among levels of other variables, which refers to the magnitude of the impact of a variable on another. Prior to analysis of variance, it was tested that the data in sub-groups such as gender and grade level meet the assumptions of normality and homogeneous of variances. To determine whether the data is distributed normally the skewness and kurtosis values is calculated and Levene's test was used to test the assumption whether sub-group variances is homogeneous. By using Pearson correlation analysis, a possible relationship between pre service science teachers' scientific epistemological beliefs and academic achievements was investigated without considering sub-dimensions of the scale.

\section{Results}

Prior statistical analysis showed regarding to four sub dimensions, data met the assumption of normality. From the calculations performed for this purpose, it was found to be the values varying between -1.0 and 1.0 for skewness and curtosis variables, which imply the satisfaction of this assumption. in addition, it was determined the groups identified according to the variables of gender and grade level without distinction of sub-dimension satisfied the assumption of normality for which values of the skewness and kurtosis value were between -1.0 and 1.0. 


\subsection{The Relationship between Scientific Epistemological Belief and Academic Achievement}

To investigate the relationship between pre service science teachers' scientific epistemological beliefs and academic achievements, the information of their grade point averages was used. In the analysis, it was used pooled data without regarding sub-dimensions of the scale. Pearson correlation conducted for this purpose indicated no statistically significant correlation between the grade point average and the belief was determined with ( $\mathrm{r}(254)=0.42 ; \mathrm{p}=0.17)$.

\subsection{The Results of the Analysis Regardless of Scale Sub Dimensions}

Descriptive statistics calculated for Epistemological belief scale regardless of scale sub dimensions, are shown in Table 1.

Table 1. Descriptive statistics calculated individually for Epistemological belief scale regardless of scale sub dimensions with respect to gender and grade level

\begin{tabular}{lllll}
\hline & & N & M & SD \\
\hline \multirow{2}{*}{ Female } & First Grade & 93 & 3,80 & 0,39 \\
& Fourth Grade & 48 & 3,94 & 0,50 \\
\multirow{2}{*}{ Male } & First Grade & 51 & 3,97 & 0,62 \\
& Fourth Grade & 66 & 3,81 & 0,43
\end{tabular}

As can be seen in Table 1, male and female students' level of epistemological belief in different grade levels for the pooled data without the discrimination of sub- scale, are notably high. Given that the highest possible score from the scale is five points, average values ranging between 3.80 and 3.97, refers to this situation. Furthermore, the Levene test for homogeneity of variances has shown that this assumption is met at the 0.05 significant level $(\mathrm{F}(3,82)=0.13, \mathrm{p}=$ 0.94). Without distinction of sub-section, the results of analysis of variance according to gender and grade level are given in Table 2.

Table 2.The results of two-way ANOVA for gender and grade level without considering distinction of sub-section

\begin{tabular}{lllllll}
\hline Source & The Sum Of Squares & Df & Mean Of Squares & F & P & $\eta^{2}$ \\
\hline Gender & $6,8.10^{-3}$ & 1 & $6,8.10^{-3}$ & 0,031 & 0,86 & 0,00 \\
Grade & $5,4.10^{-4}$ & 1 & $5,4.10^{-4}$ & 0,002 & 0,96 & 0,00 \\
$\begin{array}{l}\text { Gender* } \\
\text { Grade }\end{array}$ & 0,44 & 1 & 0,44 & 1,99 & 0,16 & 0,024 \\
\hline
\end{tabular}

It is clear from Table 2, it can be seen that it is not a significant interaction between gender and class variables $(\mathrm{p}=$ 0.16). So it is suitable to individually examine main factors. It is clear from the table, students' epistemological beliefs for the pooled data, show no difference according to gender and grade level $(\mathrm{p}=0.86$ for gender, $\mathrm{p}=0.96$ for grade level). That is, with respect to students' epistemological beliefs there are no statistically significant differences according to grade level and gender. . Below, the findings of analysis of variance for sub-sections are given individually.

\subsection{The Analysis of Sub Dimensions}

Certainty and source of scientific knowledge

According to gender and grade level variables, descriptive statistics for source of scientific knowledge (1 - 5 questions) and the certainty of scientific knowledge (6 - 11 questions) sub-dimensions are given in Table 3.

Table 3. Descriptive statistics calculated separately for source of scientific knowledge and the certainty of scientific knowledge sub dimensions

\begin{tabular}{llllllll}
\hline & & \multicolumn{2}{l}{$\begin{array}{l}\text { Source } \\
\text { Knowledge }\end{array}$} & Of & Scientific & \multicolumn{2}{l}{$\begin{array}{l}\text { Certainty } \\
\text { Knowledge }\end{array}$} \\
\hline \multirow{3}{*}{ Female } & & $\mathrm{N}$ & $\mathrm{M}$ & $\mathrm{SD}$ & $\mathrm{N}$ & $\mathrm{M}$ & Scientific \\
& Grade 1 & 93 & 3,92 & 0,64 & 93 & 3,10 & 0,72 \\
\multirow{3}{*}{ Male } & Grade 4 & 48 & 4,14 & 0,48 & 48 & 3,93 & 0,56 \\
& Grade 1 & 51 & 4,35 & 2,78 & 51 & 3,12 & 0,68 \\
& Grade 1 & 66 & 4,08 & 0,60 & 66 & 3,55 & 0,73
\end{tabular}

It was observed that assumption of homogeneous of group variances were met (Levene test) for both sub dimensions at significance level of $0.05(\mathrm{~F}(3.82)=2.56, \mathrm{p}=0.06$ for a source of scientific knowledge, and $\mathrm{F}(3,82)=0.20, \mathrm{p}=0.89$ for the certainty of scientific knowledge). 
It is clear from Table 3, for the first sub-section the average values ranged from 3.92 to 4,35, while means values for the second sub-section, certainty of scientific knowledge, is a little lower than those of first subsection, ranging 3.10 from to 3.93. The results of two ways ANOVA performed for the subsections are given in Table 4 and 5, respectively.

Table 4. The results of analysis of variance for the sub dimension source of scientific knowledge with respect to gender and grade level

\begin{tabular}{lllllll}
\hline Source & The Sum of Squares & df & Means of Squares & F & P & $\eta^{2}$ \\
\hline Gender & 0,71 & 1 & 0,71 & 0,39 & 0,53 & 0,005 \\
Grade Level & $1,58.10^{-2}$ & 1 & $1,58.10^{-2}$ & 0,009 & 0,93 & 0,00 \\
$\begin{array}{l}\text { Gender* Grade } \\
\text { Level }\end{array}$ & 1,19 & 1 & 1,19 & 0,66 & 0,42 & 0,008
\end{tabular}

Table 5. The results of analysis of variance for the sub-dimension certainty of scientific knowledge with respect to gender and grade level

\begin{tabular}{lllllll}
\hline Source & The sum of squares & df & Means of squares & F & p & $\eta^{2}$ \\
\hline Gender & 0,63 & 1 & 0,63 & 1,34 & 0,25 & 0,016 \\
Grade Level & 8,05 & 1 & 8,05 & 17,2 & 0,00 & 0,17 \\
$\begin{array}{l}\text { Gender*Grade } \\
\text { Level }\end{array}$ & 0,78 & 1 & 0,78 & 1,67 & 0,19 & 0,02
\end{tabular}

It is clear from table that the students' beliefs of source of scientific knowledge have showed no a statistical difference according to gender and grade level ( $p=0.53$ for gender and $p=0.93$ for grade level). A significant interaction between gender and grade level variables (Table 4$)$ has not been observed $(p=0.42)$. From the Table 5 , it was found that there is no any interaction between the gender and grade level variables $(\mathrm{p}=0.19)$. The analysis can be followed by main effects. The analysis of the sub-dimension certainty of scientific knowledge (Table 5) revealed the epistemological beliefs do not differ by gender level, (for gender, $p=0.25$ ). As can easily calculated from Table 3 , for first and fourth grades, means values are 3.11 and 3.74 , respectively. The statistical analysis showed that the difference was significantly significant one in favor of the fourth grade students according to grade level (for the grade level, $\mathrm{p}=0.00$ ). The eta squared $\left(\eta^{2}\right)$ value calculated for the effect, grade level was found to be 0.17 , which refers to large effect size. It means $17 \%$ of the total variance is explained by this sub-dimension.

\subsection{The Development and Justification of Scientific Knowledge}

From the analysis of data on Students' beliefs of the development of scientific knowledge (questions 12 - 17) and justification of scientific knowledge (18-26 Questions) it was calculated the number of students according to gender and grade level for sub-sections, the mean and standard deviation values are given in Table 6. From Table 6, in addition, while average values for the development of knowledge sub dimension were found to be between 3.88 and 4.14, for, average means the justification of scientific knowledge sub dimension varied from 3.78 to 4.21 which are considerably high values.

Table 6. Descriptive statistics calculated separately for the sub-dimensions the development and justification of scientific knowledge

\begin{tabular}{|c|c|c|c|c|c|c|c|c|}
\hline & & \multicolumn{2}{|c|}{$\begin{array}{l}\text { Development } \\
\text { Knowledge }\end{array}$} & & \multirow{2}{*}{$\begin{array}{l}\text { Scientific } \\
\text { SD }\end{array}$} & \multicolumn{2}{|c|}{$\begin{array}{l}\text { Justification } \\
\text { Knowledge }\end{array}$} & \multirow{2}{*}{$\begin{array}{l}\text { Scientific } \\
\text { SD }\end{array}$} \\
\hline & & $\mathrm{N}$ & $\mathrm{M}$ & & & $\mathrm{N}$ & $\mathrm{M}$ & \\
\hline \multirow[t]{2}{*}{ Female } & Grade 1 & 93 & 3,88 & & 0,65 & 93 & 3,78 & 0,67 \\
\hline & Grade 4 & 48 & 4,05 & & 0,76 & 48 & 4,15 & 0,79 \\
\hline \multirow[t]{2}{*}{ Male } & Grade 1 & 51 & 4,14 & & 0,63 & 51 & 3,83 & 0,80 \\
\hline & Grade 4 & 66 & 3,83 & & 0,61 & 66 & 4,21 & 0,66 \\
\hline
\end{tabular}

Levene test results for these sub-sections indicated the assumption was met for both (Table 6). The results of variance analysis of the sub-dimensions are given individually in Table 7 and 8. 
Table 7. The results of analysis of variance performed for the sub dimension development of scientific knowledge with respect to gender and grade level

\begin{tabular}{lllllll}
\hline Source & The sum of squares & df & Means of squares & F & p & $\eta^{2}$ \\
\hline Gender & $6,0.10^{-3}$ & 1 & $6,0.10^{-3}$ & 0,014 & 0,91 & 0,00 \\
Grade Level & $9,3.10^{-2}$ & 1 & $9,3.10^{-2}$ & 0,21 & 0,64 & 0,003 \\
$\begin{array}{l}\text { Gender*Grade } \\
\text { Level }\end{array}$ & 1,19 & 1 & 1,19 & 2,76 & 0,10 & 0,033
\end{tabular}

Table 8. The results of analysis of variance performed for the sub dimension justification of scientific knowledge with respect to gender and grade level

\begin{tabular}{lllllll}
\hline Source & The sum of squares & df & Means of squares & F & p & $\eta^{2}$ \\
\hline Gender & $6,1.10^{-2}$ & 1 & $6,1.10^{-2}$ & 0,12 & 0,73 & 0,001 \\
Grade Level & 2,84 & 1 & 2,84 & 5,5 & 0,021 & 0,063 \\
$\begin{array}{l}\text { Gender*Grade } \\
\text { Level }\end{array}$ & $1,4.10^{-6}$ & 1 & $1,4.10^{-6}$ & 0,00 & 0,99 & 0,00 \\
\hline
\end{tabular}

As can be seen in Table 7, for the sub dimension development of scientific knowledge there is also no interaction between gender and grade level variables $(p=0.10)$. Moreover, there are also no statistical significant differences according to main effects, gender and grade level ( $p=0.91$ for gender, $p=0.64$ for grade level). Table 8 showed that the interaction effect between gender and grade level is no statistically significant $(\mathrm{p}=0.99)$. Furthermore, for the last sub-dimension of the scale, "justification of the scientific knowledge", the student's epistemological beliefs showed no difference according to gender $(p=0.73)$, on contrary a significant difference was founded for grade level $(p=0.02)$ in favor of fourth grade. From Table 6, it can be easily calculated that the first and last grades' average means are 3.81 and 4.18, respectively. As shown in Table 8 , eta squared $\left(\eta^{2}\right)$ for the main effect, grade level, is 0.063 , which is counted as moderate effect size. This means the main effect explain just $6.3 \%$ of total variance.

\section{Discussion and Conclusion}

Regarding to be five the highest possible point, the average means ranging from 3.80 to 3.97 for the pooled data without considering sub dimensions of scale suggest that pre-service science teachers' epistemological beliefs are considerable high. It implies they have developed/sophisticated epistemological beliefs. Similarly, when separately examined the descriptive statistics of four different sub-dimensions it can be seen that the average means change between 3.10 and 4.35 points, which point out a considerable developed epistemological belief. In a study conducted with student teachers such as the participants of this research, Cheng et al. (2009) reported that they strongly believed to be learning effort more important than innate ability, changeability of knowledge and to be inclined to question the authority of knowledge. On contrary, In a study performed on the similar group by Tanase and Wang (2010), the authors emphasized pre-service teachers thought the teacher as the authority figure passing knowledge to the students. And they argued that in consistency with constructivist practice, these beliefs should be challenged to enable the pre-service teachers to develop alternative ideas, seeing the students capable of constructing knowledge with the help of the teacher. And they added these beliefs are found difficult to change in the course environment and some beliefs are more resistant to change than others. Again, Chan (2003) demonstrated that students believed that the view that no ability to learn is innate and no knowledge is absolute, contrary to this, their beliefs of an authority transferring knowledge from generation to generation are high.

It was revealed the individual with developed/sophisticated epistemological beliefs have high academic achievement and more effective learning (Schommer 1990; Schommer, Crouse and Rhodes 1992; Deryakulu 2002; Schommer 1993). Liang et al. (2010) showed that a deep motive for learning science could be positively affected by beliefs about the development and justification of scientific knowledge. Moreover, there are the findings emphasizing that many of the student's difficulties were epistemological in nature (Lising and Elby 2005). In study administered with pre-service teachers, the results showed epistemological beliefs had significant relationship with conceptions of learning, implying epistemological beliefs play an important role in students' learning (Chan 2011). The epistemological beliefs of teachers have influence on their choice of teaching methods and techniques, classroom management, how to arrange education and training activities (Chan and Eliot 2000). Furthermore, the beliefs had influence on the process for students to gain nature of scientific knowledge, in planning, implementation and evaluation process of teaching in their own class. Liang and Tsai (2010) determined existence of a significant relationship between students' epistemological beliefs and their attitudes toward science learning. When it was considered that students' perceptions of instructional practices are related their epistemological assumptions (Hofer 2004), it can easily be inferred that teachers' epistemological beliefs are of 
great importance in terms of training of qualified teachers. In this study, it was explored there is no statistically significant correlation between academic achievement and the epistemological belief. Accordingly, there are the findings suggesting no any relationship between academic achievement and epistemological belief (Belet and Guven 2011). But, Schreiber and Shinn (2003) indicated that students' epistemological beliefs had influence on their academic achievements which are not compatible with that of the presented study. In also other some research, it was emphasized the relationship of epistemological belief with academic achievement (Schommer 1993; Kaymak and Ogan Bekiroglu 2013; Onen 2011; Topcu and Yilmaz Tuzun 2009; Y1lmaz Tuzun and Topcu 2013; Chan, 2011; Lising, and Elby 2005).

The statistical analysis showed that there is no a statistically significant difference in pre-service science teachers' epistemological beliefs with regard to grade level and gender means in the pooled data without considering sub dimensions of scale. Then, the analysis was repeated individually for each sub dimension. For first sub dimension (question 1-5), source of scientific knowledge, there were statistical significant differences according to neither gender nor grade level. The findings from the sub dimension, development of scientific knowledge indicated that the main effects gender and grade level and gender-grade interaction were not statistically significant. In the sub dimension, certainty of scientific knowledge including questions 6-11, no statistically significant difference was found according to gender, but a significant difference for grade level. For "Justification of scientific knowledge", the last sub dimension, it was found no pre service teachers' epistemological beliefs differ with respect to gender, while there was statistically significant difference according to grade level in favor of fourth grade. For certainty of knowledge the sub dimension, while grade level effect had an effect size in medium level. However in justification of scientific knowledge dimension, the effect size magnitude was found to be small level. From the study supporting the finding of some previous research (Schommer 1993; Ozdemir and Koksal 2014; Kurt 2009; Y1lmaz Tuzun and Topcu 2013; Cano 2005; Tolhurst 2007; De-Juanas and Beltran 2012), it was indicated that two sub-dimensions of epistemological beliefs evolve through education and become more sophisticated. For example, Schommer (1993) reported the belief in simple knowledge, certain knowledge, and quick learning decreased from freshman to senior year. In this context, Ogan Bekiroglu, and Sengu Turgut (2011) underlined also the change of both students' general and physics epistemological beliefs and the improvement to higher levels. They argued that since beliefs are multidimensional, changes or improvements in one dimension of beliefs do not have to occur in other dimensions.

The findings on the change of the epistemological beliefs with respect to grade level in this study are not consistent with those of some previous research (Meral and Colak 2009; Yenice 2015), while findings of some researchers support the results (Kurt 2009; Onen 2011; Eren 2007; Akyuzluer 2014; Belet and Guven 2011; Tumkaya 2012; Aypaya 2010; Isıksal, Kurt, Dogan and Cakıroglu 2007). Any of four sub-dimensions of the scale showed no difference by gender. In literature, as well as the reports remarking the effect of gender (Schommer 1993; Aytunga 2008; Ertekin, Dilmac, Delice and Aydın 2009; Aypaya 2010; Meral and Colak 2009; De-Juanas and Beltran 2012; Belet and Guven 2011; Terzi, Sahan and Celik 2015; Deniz 2014; Onen 2011; Topcu and Y1lmaz Tuzun 2009; Er 2013; Kurt 2009; Y1lmaz Tuzun and Topcu 2013), there also are the reports raising that epistemological beliefs is independent of gender (Yenice 2015; Tumkaya 2012; Eren 2007; Kaygin, Bas, Kanbolat and İnenc 2010).In conclusion, these contradictory results suggest that in this field, further and more comprehensive studies must be conducted. The results of present study are limited with only two hundred fifty eight pre service teachers. Thus, it is clear that the research should be repeated in further similar groups to ensure the validity of the results. Moreover, it is suggested that a possible Meta analysis to be performed on this literature can be provide more reliable results.

\section{References}

Akar, E., Tekkaya, C., \& Cakiroglu, J. (2011). The interplay between metacognitive awareness and scientific epistemological beliefs. International Journal on New Trends in Education and Their Implications, 2(3).

Akyuzluer, F. (2014). Epistemologic beliefs of pre-service music teachers. Batı Anadolu Egitim Bilimleri Dergisi (BAED), 5(10), 1-15.

Aypay, A. (2011). The adaptation of the teaching-learning conceptions questionnaire and its relationships with epistemological beliefs. Educational Sciences: Theory \& Practice, 11(1), 21-29.

Aypaya, A. (2010). Teacher education student's epistemological beliefs and their conceptions about teaching and learning. Procedia Social and Behavioral Sciences, 2, 2599-2604. https://doi.org/10.1016/j.sbspro.2010.03.380

Aytunga, O. (2008). Investigation of turkish trainee teachers' epistemological beliefs. Social Behavior and Personality, 36(5), 709-718. https://doi.org/10.2224/sbp.2008.36.5.709

Bayrak, E., Cinar, V., Coban, B., \& Coskuner, Z. (2013). Prospective teachers of physical education and sport schools and faculty of education student teachers scientific epistemological beliefs in terms of different variables comparison (example of Firat University). The Journal of Academic Social Science Studies, 6(2), 1817-1828. 
Belet, S. D., \& Guven, M. (2011). Meta-cognitive strategy usage and epistemological beliefs of primary school teacher trainees. Educational Sciences: Theory \& Practice, 11(1), 51-57.

Buehl, M. M., \& Alexander, P. A. (2001). Beliefs about academic knowledge. Educational Psychology Review, 13(4), 385-418. https://doi.org/10.1023/A:1011917914756

Cano, F. (2005). Epistemological beliefs and approaches to learning: their change through secondary school and their influence on academic performance. British Journal of Educational Psychology, 75, 203-221. https://doi.org/10.1348/000709904X22683

Chan, K. (2003). Hong Kong teacher education students' epistemological beliefs and approaches to learning. Research in Education, 69, 36-50. https://doi.org/10.7227/RIE.69.4

Chan, K. W. (2011). Preservice Teacher Education Students' Epistemological Beliefs and Conceptions about Learning. Instructional Science, 39(1), 87-108. https://doi.org/10.1007/s11251-009-9101-1

Chan, K. W., \& Elliot, R. G. (2000). Exploratory study of epistemological beliefs of Hong Kong teacher education students: Resolving Conceptual and Empirical İssues. Asia- Pacific Journal of Teacher Education, 28(3), 225-234. https://doi.org/10.1080/713650691

Cheng, M. M. H., Chan, K. W., Tang, S. Y. F., \& Cheng, A. Y. N. (2009). Pre-service Teacher Education Students' Epistemological Beliefs and Their Conceptions of Teaching. Teaching and Teacher Education Volume, 25(2), 319-327. https://doi.org/10.1016/j.tate.2008.09.018

Conley, A. M., Pintrich, P. R., Vekiri, I., \& Harrison, D. (2004). Changes in epistemological beliefs in elementary science students. Contemporary Educational Psychology, 29, 186-204.

https://doi.org/10.1016/j.cedpsych.2004.01.004

Dahl, T. İ., Bals, M., \& Turi, A. L. (2005). Are students' beliefs about knowledge and learning associated with their reported use of learning strategies? British Journal of Educational Psychology, 75, 257-273. https://doi.org/10.1348/000709905X25049

De-Juanas, A., \& Beltran, J. A. (2012). Epistemological beliefs of students of pedagogy and sciences of the education. Revista De Psicodidactica, 17(1), 179-197.

Deniz, J. (2014). Epistemological beliefs of prospective music teachers. Journal of Theory and Practice in Education, 10(3), 667-683.

Deryakulu, D. (2002). The relationships among locus of control, epistemological beliefs and instructional material comprehension monitoring types and levels. Hacettepe University Journal of Education, 22, 55-61.

Enman, M., \& Lupart, J. (2000). Talented female students' resistance to science: an exploratory study of post-secondary achievement motivation, persistence, and epistemological characteristics. High Ability Studies, 11(2), 161-178. https://doi.org/10.1080/13598130020001205

Er, K. O. (2013). A study of the epistemological beliefs of teacher candidates in terms of various variables. Eurasian Journal of Educational Research, 50, 207-226.

Eren, A. (2007). Examining the differences among undergraduate students' epistemological beliefs. Education and Science, 32(145), 71-84.

Ertekin, E., Dilmac, B., Delice, A., \& Aydin, E. (2009). Teacher trainees' epistemological beliefs: effects of gender, institution and discipline (mathematics/social sciences). New Educational Review, 18(2), 184-196.

Hammer, D. (1994). Epistemological beliefs in introductory physics. Cognition and Instruction, 12(2), 151-183. https://doi.org/10.1207/s1532690xci1202_4

Havdala, R., \& Ashkenazi, G. (2007). Coordination of theory and evidence: effect of epistemological theories on students' laboratory practice. Journal of Research in Science Teaching, 44(8), 1134-1159. https://doi.org/10.1002/tea.20215

Hofer, B. K. (2001). Personal Epistemology Research: Implications for Learning And Teaching. Educational Psychology Review, 13(4), 353-383. https://doi.org/10.1023/A:1011965830686

Hofer, B. K., \& Pintrich, P. R. (1997). The development of epistemological theories: beliefs about knowledge and knowing and their relation to learning. Review of Educational Research, 67(1), 88-140. https://doi.org/10.3102/00346543067001088

Hofer, B. K. (2004). Exploring the dimensions of personal epistemology in differing classroom contexts: student interpretations during the first year of college. Contemporary Educational Psychology, 29(2), 129-163. 
https://doi.org/10.1016/j.cedpsych.2004.01.002

Isıksal M., Kurt, G., Dogan, O., \& Cakiroglu, E. (2007). Epistemological conceptions of pre-service elementary mathematics teachers: effects of university and grade level. Elementary Education Online, 6(2), 313-321.

Jehng, J. C. J., Johnson, S. D., \& Anderson, R. C. (1993). Schooling and students epitemological beliefs about learning. Contemporary Educational Psychology, 18(1), 23-35. https://doi.org/10.1006/ceps.1993.1004

Kardash, C. M., \& Howell, K. I. (2000). Effects of epistemological beliefs and topic-specific beliefs on undergraduates' cognitive and strategic processing of dual-positional text. Journal of Educational Psychology, 92(3), 524-535. https://doi.org/10.1037/0022-0663.92.3.524

Kaygin, B., Bas, F., Kanbolat, O., \& Inec, Z. F. (2010). Investigation of primary teachers' scientific epistemological beliefs according to some variables. 9. Sinif Ogretmenligi Egitimi Sетроzуити 20-22 Mayis, Elazig, 1108-1110.

Kaymak, E., \& Ogan, B. F. (2013). How students' epistemological beliefs in the domain of physics and their conceptual change are related? European Journal of Physics Education, 4(1).

Kittleson, J. M. (2011). Epistemological beliefs of third-grade students in an investigation-rich classroom. Science Education, 95(6), 1026-1048. https://doi.org/10.1002/sce.20457

Kurt, F. (2009). Investigating students' epistemological beliefs through gender, grade level, and fields of the study. Unpublished Doctoral Thesis. The Graduate School Of Social Sciences Of The Middle East Technical University, Ankara, Turkey.

Lee, S. W. Y., \& Tsai, C. C. (2012). Students' domain-specific scientific epistemological beliefs: a comparison between biology and physics. Asia-Pacific Education Researcher, 21(2), 215-229.

Liang, J. C., \& Tsai, C. C. (2010). Relational analysis of college science-major students' epistemological beliefs toward science and conceptions of learning science. International Journal of Science Education, 32(17), 2273-2289. https://doi.org/10.1080/09500690903397796

Liang, J. C., Lee, M. H., \& Tsai, C. C. (2010). The relations between scientific epistemological beliefs and approaches to learning science among science-major undergraduates in Taiwan. Asia-Pacific Education Researcher, 19(1), 43-59.

Lising, L., \& Elby, A. (2005). The impact of epistemology on learning: a case study from introductory physics. American Journal of Physics, 73(4), 372-382. https://doi.org/10.1119/1.1848115

Liu, S. Y., \& Tsai, C. C. (2008). Differences in the scientific epistemological views of undergraduate students. International Journal of Science Education, 30(8), 1055-1073. https://doi.org/10.1080/09500690701338901

Mason, L., Boscolo, P., Tornatora, M. C., \& Ronconi, L. (2013). Besides knowledge: a cross-sectional study on the relations between epistemic beliefs, achievement goals, self-beliefs, and achievement in science. Instructional Science, 41(1), 49-79. https://doi.org/10.1007/s11251-012-9210-0

Mcmillan, J. H., \& Schumacher, S. (2004). Research in Education, New York: Longman. p.

Meral, M., \& Colak, E. (2009). An investigation of student-teachers' scientific epistemological belief. Ondokuz Mayis Universitesi Egitim Fakultesi Dergisi, 27, 129-146.

Ogan, B. F., \& Sengul, T. G. (2011). Students' general and physics epistemological beliefs: a twofold phenomenon. Research in Science \& Technological Education, 29(3), 291-314. https://doi.org/10.1080/02635143.2011.594790

Oksal, A., Sensekerci, E., \& Bilgin, A. (2006). Development of the central epistemological beliefs scale: the validity and reliability study. Uludag Universitesi Egitim Fakultesi Dergisi, 19(2), 371-381.

Onen, A. S. (2011). Investigation of students' epistemological beliefs and attitudes towards studying. Hacettepe Universty Journal of Education, 40, 300-309.

Ozdemir, I., \& Koksal, N. (2014). The evaluation of elementary scool teachers' epistemological beliefs. Ankara University Journal of Faculty of Educational Sciences, 47(1), 301-326.

Palmer, B., \& Marra, R. M. (2004). College student epistemological perspectives across knowledge domains: a proposed grounded theory. Higher Education, 47(3), 311-335. https://doi.org/10.1023/B:HIGH.0000016445.92289.f1

Perry, W. G. (1981). Cognitive and ethical growth: the making of meaning. In Chickering, A. (ed.), The Modern American College, Jossey-Bass, San Francisco, 76-116.

Pulmones, R. (2010). Linking students' epistemological beliefs with their metacognition in a chemistry classroom. 
Asia-Pacific Education Researcher, 19(1), 143-159. https://doi.org/10.3860/taper.v19i1.1514

Ravindran, B., Greene, B. A., \& Debacker, T. K. (2005). Predicting preservice teachers' cognitive engagement with goals and epistemological beliefs. Journal of Educational Research, 98(4), $222-232$. https://doi.org/10.3200/JOER.98.4.222-233

Rizk, N., Jaber, L., Halwany, S., \& Boujaoude, S. (2012). Epistemological beliefs in science: an exploratory study of lebanese university students' epistemologies. International Journal of Science and Mathematics Education, 10(3), 473-496. https://doi.org/10.1007/s10763-011-9289-9

Saylan, A., Bektas, O., \& Oner, A. F. (2015). Investigation of the relationship between pre-service science teachers' epistemological beliefs and beliefs about nature of science. Mevlana International Journal of Education (MIJE), 5(2), 96-116.

Schommer, A. M., Beuchat, R. M., \& Hernandez, P. F. (2012). Epistemological and learning beliefs of trainee teachers studying education. Anales De Psicologia, 28(2), 465-474.

Schommer, M. (1990). Effects of beliefs about the nature of knowledge on comprehension. Journal of Educational Psychology, 82, 498-504. https://doi.org/10.1037/0022-0663.82.3.498

Schommer, M. (1993). Epistemological development and academic-performance among secondary students. Journal of Educational Psychology, 85(3), 406-441. https://doi.org/10.1037/0022-0663.85.3.406

Schommer, M., \& Walker, K. (1995). Are epistemological beliefs similar across domains. Journal of Educational Psychology, 87(3), 424-432. https://doi.org/10.1037/0022-0663.87.3.424

Schommer, M., Crouse, A., \& Rhodes, N. (1992). Epistemological beliefs and mathematical text comprehension: believing it is simple does not make it so. Journal of Educational Psychology, 4, 453-443. https://doi.org/10.1037/0022-0663.84.4.435

Schreiber, B. J., \& Shinn, D. (2003). Epistemological beliefs of community college students and their learning processes. Community College Journal of Research and Practice, 27, 699-709. https://doi.org/10.1080/713838244

Tanase, M., \& Wang, J. A. (2010). Initial epistemological beliefs transformation in one teacher education classroom: case study of four preservice teachers. Teaching and Teacher Education, 26(6), 1238-1248. https://doi.org/10.1016/j.tate.2010.02.009

Terzi, A. R., Sahan, H. H., \& Celik, H. (2015). The relation between teacher candidates' epistemological beliefs and critical pedagogy principles. Journal of Research in Education and Teaching, 4(1).

Tolhurst, D. (2007). The Influence of learning environments on students' epistemological beliefs and learning outcomes. Teaching In Higher Education, 12(2), 219-233. https://doi.org/10.1080/13562510701191992

Topcu, M. S. (2011). Turkish elementary student teachers' epistemological beliefs and moral reasoning. European Journal of Teacher Education, 34(1), 99-125. https://doi.org/10.1080/02619768.2010.534132

Topcu, M. S., \& Yilmaz, T. O. (2009). Elementary students' metacognition and epistemological beliefs considering science achievement, gender and socioeconomic status. Elementary Education Online, 8(3), 676-693.

Tsai, C. C. (1999). "Laboratory exercises help me memorize the scientific truths": a study of eighth graders' scientific epistemological views and learning in laboratory activities. Science Education, 83(6), 654-674. https://doi.org/10.1002/(SICI)1098-237X(199911)83:6<654::AID-SCE2>3.0.CO;2-Y

Tumkaya, S. (2012). The investigation of the epistemological beliefs of university students according to gender, grade, fields of study, academic success and their learning Styles Educational Sciences: Theory \& Practice, 12(1), 88-95.

Yenice, N. (2015). An analysis of science student teachers' epistemological beliefs and metacognitive perceptions about the nature of science. Educational Sciences: Theory \& Practice, 15(6), 1-14. https://doi.org/10.12738/estp.2015.6.2613

Yenice, N., \& Ozden, B. (2013). Analysis of scientific epistemological beliefs of eighth graders. International Journal of Education in Mathematics, Science and Technology, 1(2), 107-115.

Yildiran, D., Demirci, N., Tuysuz, M., Bektas, O., \& Geban, O. (2011). Adaptation of an epistemological belief instrument towards chemistry and chemistry lessons. WCES-2011, Procedia Social and Behavioral Sciences, 15, 3718-3722. https://doi.org/10.1016/j.sbspro.2011.04.362

Yilmaz, T. O., \& Topcu, M. S. (2013). Exploration of preservice science teachers' epistemological beliefs, world views, and self-efficacy considering gender and achievement. Elementary Education Online, 12(3), 659-673. 
Zinn, B. (2012). A pilot study of the epistemological beliefs of students in industrial-technical fields. International Journal of Technology and Design Education, 22(3), 361-375. https://doi.org/10.1007/s10798-011-9153-9

\section{Copyrights}

Copyright for this article is retained by the author(s), with first publication rights granted to the journal.

This is an open-access article distributed under the terms and conditions of the Creative Commons Attribution license which permits unrestricted use, distribution, and reproduction in any medium, provided the original work is properly cited. 